$3(30) / 2015$

\title{
Dietrich Benner
}

Humboldt Universität zu Berlin, Deutschland

dietrich.benner@cms.hu-berlin.de

\section{Dariusz, Stepkowski}

Uniwersytet Kardynała Stefana Wyszyńskiego w Warszawie

d.stepkowski@uksw.edu.pl

\section{Pojęcie ukształcalności i jego miejsce w teorii wychowania Jeana Jacquesa Rousseau ${ }^{1}$}

\section{Summary}

The concept of perfectibilité and its place in Jean Jacques Rousseau's theory of education

The philosophical and pedagogical work of Jean Jacques Rousseau still raises many disputes and polemical debates. In this article, the authors focus on only one concept-perfectibilité, which is, according to them, the key to understanding his theories. By using the concept of perfectibilité, Rousseau defines the ambivalent characteristic of modern man, i.e., his ontological need to learn. The article consists of three parts. In the first, the authors try to locate the concept of perfectibilité in Rousseau's philosophical and pedagogical texts. In the second, the meaning of the term is reconstructed in relation to the conditions of becoming a man. Finally, in the third, the project of upbringing and education from Rousseau's Emil is re-read.

Słowa kluczowe: Rousseau, kształcenie, ukształcalność, teoria wychowania

Keywords: Rousseau, education, perfectibilité, theory of education

\section{Wprowadzenie}

Lata życia Jeana Jacques’a Rousseau przypadły na schyłkowy okres ancien régime, feudalnego systemu własności i formy rządów, w której urodzenie decydowało o przyporządkowaniu do jednej z grup społecznych: chłopstwa, rzemieślników, wolnych zawodów, kleru lub szlachty. Z wymienionych tylko ci ostatni mogli pełnić, mówiąc językiem współczesnym, funkcje kierownicze w państwie, oczywiście pod czujnym okiem absolutystycznego monarchy. Gdy w 1789 roku wraz z wybuchem rewolucji francuskiej rozpadł

\footnotetext{
1 Artykuł jest zmodyfikowaną wersją jednego z rozdziałów monografii autorstwa Dietricha Bennera, Alexandra von Oettingena, Zhengmei Penga i Dariusza Stępkowskiego pt. Bildung - Moral-Demokratie. Theorien und Konzepte moralischer Erziehung und Bildung und ihre Beziehungen zu Ethik und Politik (2015, Parerborn, Ferdinand Schöningh Verlag). Praca ukaże się w całości w języku polskim w Wydawnictwie Uniwersytetu Kardynała Stefana Wyszyńskiego w Warszawie w 2016 roku.
} 
się ów porządek, autor Emila nie żył już od ponad 10 lat. Mimo że przeczuwał nadejście radykalnej zmiany, to jednak trudno zgodzić się z dość powszechnie panującym przekonaniem, że był on heroldem rewolucji francuskiej.

To, jak Rousseau patrzył na człowieka i jego dziejowe usytuowanie, cechuje zbieżność z poglądami renesansowego myśliciela Giovanniego Pico della Mirandoli, wyrażonymi w jego słynnym traktacie Mowa o godności człowieka (2010). Równocześnie jednak obaj autorzy różnią się od siebie zdecydowanie. Te podobieństwa i różnice warunkują się wzajemnie w ścisły sposób. W dziele Pico della Mirandoli, traktującym o wielkości człowieka nowożytnego, który zaczyna panować nad światem i uświadamiać sobie, że jest niepowtarzalną indywidualnością, dominuje optymistyczny nastrój przełomu. U Rousseau do tego nastroju dołącza się doświadczenie ambiwalencji postępu i przeżycie wewnętrznego rozdarcia, jakie niesie on ze sobą. Zapewne z tego właśnie powodu Friedrich Nietzsche nazwał Rousseau pierwszym człowiekiem nowoczesnym.

W tym artykule koncentrujemy się na pojęciu perfectibilité, które tłumaczymy na język polski z pomocą słowa „ukształcalność”2. Naszym zdaniem perfectibilité wyraża zasygnalizowaną powyżej kondycję człowieka nowoczesnego i stanowi klucz do zrozumienia dzieł filozoficzno-pedagogicznych Rousseau. Nasza uwaga nie skupia się jednak na słownikowym sensie tego terminu, lecz na jego odniesieniach do fundamentalnych kwestii współczesnego myślenia i działania pedagogicznego. Tak więc najpierw zrekonstruujemy obecność terminu perfectibilité w pismach Rousseau. Następnie rozważymy jego innowacyjny potencjał w odniesieniu do rozumienia społecznych uwarunkowań stawania się człowiekiem. Na zakończenie przedstawimy opisany w Emilu projekt wychowania i kształcenia, u którego podstaw spoczywa idea nieokreślonej ukształcalności człowieka.

\section{W poszukiwaniu prawdziwej natury czlowieka}

Bez zbytniej przesady można powiedzieć, że Rousseau zdobył sławę w przeciągu jednej nocy. Jako nikomu jeszcze nieznany myśliciel przesłał w 1750 roku do Akademii w Dijon rozprawę odpowiadającą na pytanie konkursowe: „Czy odrodzenie nauk i sztuk przyczyniło się do naprawy obyczajów?” (Rousseau 1956a: 9). Odpowiedź Rousseau brzmiała jednoznacznie - nie. Za tę odpowiedź przyznano mu główną nagrodę. Gdy jednak pięć lat później ta sama akademia rozpisała kolejny konkurs, pytając tym razem o przyczyny nierówności panujących między ludźmi, i Rousseau ponownie przesłał swój tekst, w którym rozróżnił między naturalną i społeczną nierównością, wykazując, że nierówności istniejące w społeczeństwie francuskim są w głównej mierze spowodowane porządkiem społecznym opartym na feudalistycznym systemie własności i władzy absolutystycznej, jego odpowiedź pozostała bez nagrody.

W drugim ze wskazanych powyżej traktatów, a mianowicie Rozprawie o pochodzeniu i podstawach nierówności między ludźmi z 1755 roku Rousseau twierdzi odnośnie do

2 W sprawie polskiej etymologii terminu ,ukształcalność” i jego recepcji por. D. Stępkowski (2010). 
natury człowieka, że wyróżnia ją specyficzna cecha, którą oddał z pomocą terminu perfectibilité. Cecha ta w jednakowym stopniu przysługuje jednostkom, jak i całemu gatunkowi ludzkiemu. Jest ona zdolnością rozwijania zdolności. Na jej temat Rousseau pisze:

Ale gdyby nawet [...] wspomniana różnica między człowiekiem a zwierzęciem mogła być jeszcze przedmiotem niejakiej dyskusji, to dzieli ich jeszcze inna właściwość, bardzo specyficzna, i która wątpliwości już nie podlega: jest to zdolność doskonalenia się (perfectibilité), zdolność, dzięki której, w miarę okoliczności, wszystkie inne kolejno dochodzą do rozwoju, a która tkwi zarówno w całym ludzkim gatunku, jak i w każdym poszczególnym człowieku; zwierzę natomiast jest po kilku miesiącach tym, czym będzie przez całe życie, gatunek zaś jego po lat tysiącu tym, czym był w pierwszym roku tego tysiąca. Dlaczegoż to tylko człowiek może zdziecinnieć? Czyż nie ta jest przyczyna, że wraca on w ten sposób do swego stanu pierwotnego i że gdy zwierzę, które nic nie zdobyło i nie ma również nic do stracenia, zawsze pozostaje przy swym instynkcie, człowiekowi starość lub jakieś inne przypadłości mogą odebrać wszystko, co był zdobył dzięki zdolności doskonalenia się, i że wtedy spada on poniżej zwierzęcia? (Rousseau 1956b: 155).

W tym fragmencie odnajdujemy wprowadzone przez Pico della Mirandolę pojęcie otwartej, niezdeterminowanej zdolności człowieka do uczenia się, która jest ambiwalentna i wolna od ukierunkowania na jakikolwiek telos (Pico della Mirandola 2010: 39). To, że człowiek musi od chwili urodzenia uczyć się wszystkiego i niczego, czego się sam nauczył, nie jest w stanie przekazać swojemu potomstwu drogą dziedziczenia, uchodzi zdaniem Rousseau za jedyne prawomocne przypuszczenie, jakie można sformułować odnośnie do ludzkiej natury. Ukształcalność lub zdolność do uczenia się jak kamień milowy znaczy początek historii każdego człowieka i jego wejście na drogę powołania, na której nie ma on żadnego celu ustalonego z góry przez naturę.

Stosowany przez Rousseau termin perfectibilité scala opracowane przez Pico della Mirandolę pojęcie godności człowieka, dzięki której może on „wyrodzić się (degenerare) w niższe stworzenia, w zwierzęta” (tamże: 39) albo ,zostać odrodzony (regenerari) [...] w istotach wyższych i boskich" (tamże: 39), z refleksją na temat skończoności ludzkiej egzystencji. W ten sposób dochodzi do konfrontacji renesansowego optymizmu z pierwszymi doświadczeniami budowania społeczeństwa republikańskiego opartego na równości, wolności i braterstwie. Rousseau wyraźnie dostrzega panującą między ludźmi różnorodność, ale nie wyprowadza jej z natury, lecz z warunków życia ukształtowanych przez koegzystencję w formacjach społecznych wykrystalizowanych w ciągu dziejów ludzkości. Te warunki właśnie osłabiły zdolność człowieka do doskonalenia się, jego ukształcalność. Według Rousseau ludzie już dawno temu stoczyli się pod wieloma względami poniżej poziomu zwierząt. Zwierzęta bowiem zabijają inne zwierzęta jedynie wtedy, gdy odczuwają głód; konkurowanie między osobnikami tego samego gatunku trwa tylko do momentu zdobycia uznania dla własnej przewagi. Inaczej jest natomiast z człowiekiem nowożytnym. Ponieważ uważa on, że jest uprawniony do realizowania wyłącznie swoich własnych celów, stał się istotą pozbawioną umiaru. Miejsce renesansowego optymizmu 
odnośnie do idei postępu ludzkości zajmuje u Rousseau sceptyczna, aczkolwiek niepozbawiona całkowicie nadziei, interpretacja historii. Z pewnym zdziwieniem można w niej odnaleźć to samo, na co dwieście lat później zwrócili uwagę Max Horkheimer i Theodor W. Adorno w Dialektyce oświecenia (2010), twierdząc, że oświeceniu i postępowi nieustannie zagraża niebezpieczeństwo zwyrodnienia w barbarzyństwo. Analizując ludzkie dzieje, Rousseau podkreśla, że człowiek nie tylko coraz bardziej podporządkowuje sobie przyrodę, lecz równocześnie siebie samego poddaje panowaniu, które coraz bardziej ogranicza i zawęża jego perfectibilité. Wprawdzie niezmiennie dana mu jest zdolność do niezdeterminowanego uczenia się, jednak robi z niej opaczny użytek (Reitmeyer 2013).

Na początku pierwszej księgi Emila Rousseau dowodzi, że upadek ludzkiej natury wiąże się nierozerwalnie z ukształcalnością człowieka. Pisze on następująco:

Wszystko wychodząc z rąk Stwórcy jest dobre, wszystko wyrodnieje w rękach człowieka. Zmusza on glebę do karmienia płodów właściwych innej glebie, drzewo do wydawania owoców właściwych innemu drzewu; miesza i plącze klimaty, żywioły, pory roku; kaleczy swego psa, swego konia, swego niewolnika; wszystko przeinacza i wszystko oszpeca; lub zniekształcenia i potwory; nie chce niczego takim, jak je stworzyła natura, nawet człowieka: musi go tresować jak konia w ujeżdżalni; musi go urabiać na swoją modłę jak drzewo w swoim ogrodzie (Rousseau 1955a: 7).

Bonté naturelle (naturalna dobroć), o której powyżej jest mowa, nie jest historycznie uwarunkowaną otwartością, jaką według Pico della Mirandoli i Rousseau człowiek ma wydobywać z siebie samego dzięki samodzielnemu myśleniu i działaniu. Jest ona raczej takim ukonstytuowaniem człowieka, które zostało mu nadane przez Stwórcę w postaci zdolności rozwijania zdolności, czyli ukształcalności. Ta ukształcalność jest warunkiem sine qua non wejścia pojedynczego człowieka i ludzkiego gatunku w dzieje.

To, że człowiek musi samodzielnie dążyć do dobra i w miarę swoich sił je urzeczywistniać, nie jest dla Rousseau bynajmniej żadnym brakiem, lecz specyficznym rysem ludzkiej natury jako ukształcalnej. Istota obdarzona taką naturą wyłamuje się spod zdeterminowania pochodzącego od czynników przyrodniczych, mimo że pozostaje na nie otwarta. Rousseau pisząc: ,wszystko wyrodnieje w rękach człowieka”, chce dać do zrozumienia, że nie tylko człowiek jest ukształcalny, lecz również cały świat. Jednak w tej aktualizującej się w sprzężeniu zwrotnym między człowiekiem a światem ukształcalności tkwi pewna ambiwalencja. Rousseau eksplikuje ją, dołączając do wypowiedzi na temat tego, że wszystko jest dobre i wszystko wyrodnieje w rękach człowieka, jeszcze trzecią myśl. W wielu interpretacjach nie zauważa się jej w ogóle lub bagatelizuje. Brzmi ona następująco:

Inaczej jednak [tj. bez perfectibilité, czyli ukształcalności - dop. D.B., D.S.] byłoby jeszcze gorzej. Rodzaj nasz nie chce być kształtowany połowicznie. W tym stanie, w jakim się obecnie rzeczy znajdują, człowiek, pozostawiony od urodzenia samemu sobie, byłby wśród innych najbardziej zniekształcony (tamże: 7). 
Wrodzona człowiekowi dobroć utożsamia się z jego nieokreśloną ukształcalnością. Nie chodzi jednak o żadną jakość moralną czy etyczną, lecz o to, że jest dobrze, że człowiek ze swej natury dysponuje ambiwalentną ukształcalnością. To, że wszystko, co znajdzie się w jego rękach, ulega zwyrodnieniu i przekształca się na gorsze, wyzwala go spod teleologicznego ukierunkowania na zdefiniowane z góry, odwieczne cele. Według Rousseau do ludzkiej natury, której przysługuje nieokreślona ukształcalność, przynależy jeszcze konieczność polegająca na tym, że człowiek musi sam siebie ukonkretnić przez aktywowanie posiadanej ukształcalności w zwrotnych interakcjach ze światem. Dopiero wówczas, gdy te trzy wypowiedzi odczyta się razem, widać wyraźnie nowoczesne ujęcie starożytnego rozróżnienia między trzema częściami dynamicznej natury człowieka - częścią epimejską, prometejską i tą odwołującą się do boskości (Benner i in. 2015: 22-31). To właśnie było przedmiotem rozważań Rousseau, gdy w kontekście nowożytności zastanawiał się nad właściwym porządkiem natury.

\section{Ukształcalność jako produkt uspolecznienia?}

Rousseau poddaje daleko idącej krytyce formacje społeczne uzurpujące sobie prawo do nadprzyrodzonego ukierunkowania na samoistny porządek celowościowy. Uważa bowiem, że wszystkie formy ludzkiej koegzystencji zostały wytworzone w ciągu dziejów. Wewnętrznym napędem jego krytyki jest pytanie: czy w tych formacjach panuje harmonia między ludzką ukształcalnością a historycznie zdeterminowaną formą uspołecznienia?

To, czy da się w ogóle udzielić odpowiedzi na powyższe pytanie, jest problemem odnoszącym się do samych podstaw analizowanego zagadnienia. $\mathrm{Z}$ tą sprawą Rousseau zmierzył się zarówno w sposób systematyczny, jak i historyczny. Zasadnicze pytanie brzmi: czy można na podstawie doskonalącej się ludzkiej natury formułować jakiekolwiek wypowiedzi na temat tego, jakie historyczno-społeczne determinanty są zgodne z tą naturą, a jakie nie? Czy mając do dyspozycji pojęcie nieokreślonej ukształcalności, które wskazuje raczej, czym ukształcalność nie jest, niż czym ona jest, da się rozróżnić między formami ludzkiego współbycia uzgadniającymi się z warunkami naturalnymi a tymi, które są z nimi sprzeczne? Czy te i tym podobne rozróżnienia nie powinny być przeprowadzane na podstawie historyczno-społecznej analizy konkretnej formacji społecznej, z uwzględnieniem niedającej się uniknąć konsekwencji, że będąc „tylko” analizami historyczno-społecznymi, nie powinny być nazywane naturalnymi? (Schäfer 2009: 237 i nast.).

Rozstrzygnięcie powyższych kwestii zawiera Rozprawa o naukach $i$ sztukach z 1750 roku. Rousseau nawiązuje w niej do prawa naturalnego i operuje argumentacją przypominającą krytykę transcendentalno-filozoficzną. $Z$ tego właśnie punktu widzenia polemizuje z poglądami Thomasa Hobbesa. Jego tok myślenia można zrekonstruować następująco: jeżeli chce się uniknąć w argumentowaniu błędnego koła, to nic, co zostało przyjęte jako produkt zapośredniczenia historyczno-społecznego, nie może być utożsamiane z naturą człowieka. Taki właśnie błąd popełnił jednak Hobbes, który z historyczno-społecznie określonej kondycji ludzi swoich czasów wysnuł wniosek odnośnie do pierwotnej na- 
tury człowieka. Angielski filozof narzeka na toczące się w jego czasach wojny religijne i w celu przeciwdziałania im domaga się powstania silnego państwa, które okiełzna naturę człowieka postępującego wobec innych jak wilk (homo homini lupus). Uleczenie z „naturalnej" wrogości ma się dokonać przez podporządkowanie każdego prawu państwowemu. W swojej krytyce Rousseau wykazuje, że Hobbes bezzasadnie utożsamił specyficzną sytuację społeczną swoich czasów (wojnę wszystkich przeciw wszystkim) z ogólną naturą człowieka i zamiast zająć się określeniem specyfiki bycia człowiekiem, próbował go opisać na podstawie doświadczenia społecznego. Na marginesie można dodać, że podobny błąd obciąża analizy przeprowadzone przez Margaret Mead. Dwudziestowieczna antropolog kultury przetransponowała zaobserwowane przez siebie cechy sposobu życia ludów Oceanii na rzekomo pierwotną naturę człowieka, twierdząc, że jest w stanie dowieść tego, że człowiek z racji swojej natury jest skłonny do pokojowej koegzystencji. Także tutaj natrafiamy na błąd petitio principii, który u Mead dodatkowo jest związany z tym, że jej badania były selektywne i w niedostatecznym stopniu uwzględniały empiryczne dowody ambiwalencji zachowań obserwowanych przez nią osób (Freeman 1983).

Rousseau ze swojej krytyki Hobbesa wyciąga następujący wniosek: nieuprawnione jest przenoszenie cech mających źródła społeczne na stan natury i dlatego należy chronić się przed umieszczaniem w naturze człowieka czegokolwiek, co powstało nie naturalnie, lecz na drodze rozwoju historyczno-społecznego. Pojęcie ludzkiej natury nie jest zatem pojęciem empirycznym, lecz hipotetycznym, mówiąc dokładniej: jest to termin odnoszący się do ludzkiej natury pozbawionej cech pochodzących z życia społecznego. Jako konstrukcja teoretyczna pojęcie natury pozwala na uniknięcie błędnego koła, jakiemu ulegli m.in. Arystoteles i Hobbes.

Zgodnie z powyższym użyteczne jest tylko takie pojęcie natury, które powstało na drodze abstrahowania od historyczno-społecznych uwarunkowań ludzkiego życia jako termin transcendentalny i wskutek tego niemówiący nic o tym, jaka jest natura człowieka na podstawie empirycznie kontrolowalnych przesłanek, lecz utworzony na drodze rozumowania hipotetycznego. W tym rozumowaniu chodzi o prześledzenie tego, jak należy pomyśleć ludzką naturę, żeby uniknąć błędnego koła argumentowania, w którym fakty społeczne uznawane są za naturalne. Dzięki tak uzyskanemu terminowi staje się konieczne analityczne i refleksyjne sprawdzenie historyczno-społecznych założeń ważności stosowanych określeń natury. Rousseau pisze na ten temat następująco:

Zacznijmy więc od tego, że odrzucimy wszelkie fakty, gdyż nie mają one związku z problemem. Wyniki badań, w które się przy tym temacie można zapuścić, należy brać nie za prawdy historyczne, lecz jedynie za rozważania hipotetyczne i warunkowe, bardziej się nadające do wyjaśnienia istoty rzeczy niż do wskazania ich rzeczywistego początku i podobne do tych, które na temat powstania świata codziennie spotykamy u przyrodników (Rousseau 1956b: 141).

Rousseau mając świadomość tego, że trzeba unikać błędnego koła interpretowania stanów rzeczy zapośredniczonych przez historię i społeczeństwo jako naturalnych, wie równo- 
cześnie, że wcale nie jest tak łatwo to zrobić. W przywołanej powyżej rozprawie poprzedza swoje wywody łacińskim przekładem fragmentu Polityki Arystotelesa, aby pokazać, dlaczego arystotelesowska droga poznania budziła od zawsze wątpliwości, a w obecnych warunkach jest nie do zaakceptowania. Wspomniany fragment brzmi następująco: „Non in depravatis, sed in his quae bene secundum naturam se habent, considerandum est quid sit naturale” (tamże: 105). To zdanie w przekładzie na język polski ma postać: „Należy jednak, gdy chodzi o ustalenie zgodności z naturą, brać pod uwagę stan normalny, a nie wykolejenia" (Arystoteles 2001:30 [1254a 35]).

W kontekście całości wywodów Rousseau można stwierdzić, że przeciwstawia się on powyższemu stanowisku Arystotelesa, według którego poznanie tego, co normalne w życiu politycznym, jest uzależnione od szczególnych okoliczności. Gdyby ich zabrakło, nie dałoby się rozpoznać natury jako takiej ani jej społecznego zapośredniczenie. Żeby uniknąć popadnięcia w błędne koło, trzeba zdaniem Rousseau przyjąć zupełnie inne założenie. Brzmi ono tak: zrekonstruowanie tego, co naturalne w człowieku, jest niemożliwe do przeprowadzenia w społeczeństwie. To właśnie przekonanie przyświecało powstaniu Emila i odnajdujemy je w formie sądu pozytywnego w jednym z jego fragmentów, w którym autor odnośnie do ludzkiej zdolności doskonalenia, czyli ukształcalności twierdzi: Nous ignorons ce que nôtre nature nous permet d'être, co autor polskiego przekładu oddał następująco: „Nie wiemy, czym natura nasza pozwala nam być” (Rousseau 1955a: 46).

Przedstawiona powyżej koncepcja ukształcalności nie określa bynajmniej, kim jest człowiek, ale otwiera przed nim nieskończoną możliwość stawania się dzięki otwartej i niezdeterminowanej ukształcalności. Poniżej zostanie prześledzona odpowiedź udzielona przez Rousseau na pytanie o to, jak możliwe jest kultywowanie owej nieokreślonej natury. Przestrzenią, w której ten problem zostanie rozważony jest edukacja.

\section{Ukształcalność jako podstawa współczesnej edukacji}

Pedagogiczna odpowiedź na pytanie o możliwość zachowania nieokreślonej ukształcalności została przedstawiona przez Rousseau w jego słynnej powieści edukacyjnej Emil. Przez samego autora powieść ta nie była rozumiana jako wprowadzenie do praktycznego wychowania, lecz jako tekst, w którym poddano refleksji hipotetyczny projekt nowoczesnego wychowania i nauczania. Adresatami rozważań Rousseau są dorośli, którzy powinni zweryfikować swoje dotychczasowe wyobrażenia na temat wychowania dzieci i młodzieży. W tym właśnie sensie w Przedmowie Rousseau pisze następująco:

Nie znamy zupełnie dzieciństwa: wobec błędnych na nie poglądów, im dalej się zapuszczamy, tym bardziej błądzimy. Najmądrzejsi przykładają się do tego, co człowiek powinien wiedzieć, nie zwracając uwagi na to, czego dziecko może się nauczyć. Szukają zawsze w dziecku człowieka nie myśląc o tym, czym jest ono, zanim jeszcze stanie się człowiekiem. Tym właśnie badaniom oddałem się z największą pilnością, ażeby można było korzystać z moich spostrzeżeń wówczas nawet, gdyby cała metoda moja była urojona i fałszywa. Być może, iż źle pojąłem, co trzeba robić, ale zdaje mi się, żem dobrze poznał istotę, na którą 
trzeba działać. Zacznij więc od lepszego poznania swego ucznia: z największą bowiem pewnością nie znasz go zupełnie; otóż o ile w tym właśnie celu czytać będziesz tę książkę, nie sądzę, by miała być dla ciebie bez pożytku (tamże: 4).

Powody nieznajomości dzieciństwa są wielorakie. Po pierwsze, dorośli patrzą na dziecko z perspektywy kogoś, kto już umie to, czego dziecko będzie się dopiero uczyło. Takie patrzenie dorosłych rozmija się z sytuacją, w której znajduje się dziecko, gdy się uczy. Po drugie, dorośli zapomnieli swoje własne (wczesne) dzieciństwo i nie potrafią - choćby nawet tego chcieli - przypomnieć sobie tego okresu swojego życia, kiedy nie potrafili chodzić czy mówić. Po trzecie, dorosłym brak wiedzy o tym, kim dziecko będzie w przyszłości i stąd chętnie patrzą na nie jak na reprezentanta określonego stanu czy grupy zawodowej, tracąc przez to z oczu zarówno nieokreśloną przyszłość dziecka, jak i jego otwartą i niezdeterminowaną ukształcalność. Reasumując, podjęte pytania i problemy zapowiadają nadejście nowego rodzaju stosunku międzypokoleniowego, w którym pokolenie dorosłych nie będzie antecedencją przyszłości dostających, lecz samo będzie musiało się zmierzyć z własną niepewną i kontyngentną przyszłością.

W błędzie byliby rodzice, którzy sądziliby, że mają wychowywać swoje dziecko zgodnie ze wskazaniami Rousseau. Zamiast je obserwować, chcieliby naśladować czynności wychowawcze podejmowane przez Jana Jakuba. Na czym ma polegać wychowanie zgodne z ukształcalnością, w którym zamiast naśladowania rzekomego odkrywcy dzieciństwa i jego metod wychowawczych, kładzie się nacisk na samodzielne studiowanie i badanie nieznanego i nigdy niedającego się poznać do końca dzieciństwa?

W swoich dziełach Umowa społeczna i Emil, które ukazały się krótko po sobie w roku 1762, Rousseau nie zaprezentował gotowej odpowiedzi na palące pytania swojej epoki, lecz tylko hipotetyczne rozważania stojące względem siebie w zastanawiającym stosunku warunkowania. Teoretyczne zapisy traktatu społecznego da się przekuć w praktykę życia tylko mając do czynienia z ludźmi, którzy wcześniej zostali wychowani na zasadach opisanych w Emilu. Natomiast zasady te okazują swoją praktyczną wartość dopiero w warunkach republikańskiego czy demokratycznego porządku społecznego. Oba te warunki za życia Rousseau nie były spełnione. Stąd też w Umowie społecznej opracował on zasady praworządności państwowej, w Emilu zaś zasady działania pedagogicznego. Gdy jednak czyta się je razem, otrzymujemy hipotetyczną teorię wychowania holistycznego. Tej teorii Rousseau nadał formę powieści literackiej po to, żeby na wymyślonym przykładzie edukacji Emila wyjaśnić ją jak najprzystępniej.

W teorii nowoczesnego wychowania autorstwa Rousseau można wyróżnić trzy zasady, a mianowicie: (1) zasadę wychowania przez przyrodę, (2) zasadę wychowania przez przedmioty i (3) zasadę wychowania przez innych ludzi. Na pierwszy rzut oka wydaje się, że mamy tutaj do czynienia z tautologią, która przez odwołanie do przyrody chce wyjaśnić to, co naturalne, natomiast z pomocą pojęcia interakcji eksplikuje doświadczenia związane z rzeczami i ludźmi. W tym kontekście zasada wychowania naturalnego orzeka, że jest nim ,wychowanie przez przyrodę”. O uczeniu się przez doświadczenie można 
powiedzieć, że postępuje ono zgodnie z „zasadą wychowania przez przedmioty”. Z kolei o interakcjach pedagogicznych, że są ,wychowaniem przez innych ludzi”. Jeżeli jednak odczytywać te zasady z perspektywy pytań wynikających z historii problemów pedagogicznych, którą to historię można prześledzić wstecz aż do Platońskiej opowieści o jaskini (Benner, Stępkowski 2012), to wówczas zniknie ich tautologiczny charakter. Wtedy również ukaże się w całej pełni podejście do Rousseau, które nie gloryfikuje go jako odkrywcy nowożytnego dzieciństwa ani protagonisty ruchu wzywającego do „powrotu do natury”, lecz uważa go za współtwórcę nowoczesnej pedagogiki. Jako jej „ojciec-założyciel” Rousseau opracował teorię wychowania negatywnego, która jest głęboko zakorzeniona w refleksji na temat produktywności negatywnego doświadczenia, obejmującej okres od starożytności do współczesności.

Przez wychowanie z pomocą przyrody Rousseau rozumie to, co Platon we wspomnianej powyżej opowieści o jaskini wyraził za pomocą natury ludzkiej rozpiętej między kształceniem a jego brakiem, z tą jednak różnicą, że autor Emila nie wyjaśnia ukształcalnej natury człowieka na wymyślonym przykładzie dorosłych mieszkańców jaskini, lecz przenosi ją na okres wczesnego dzieciństwa. Drugą różnicą jest ta, że Rousseau nie snuje swoich rozważań na temat kształcenia człowieka w sensie starożytnej paidei, lecz z perspektywy nowożytnego wychowania dzieci i młodzieży. Wychodząc od nieokreśloności ludzkiej natury, wychowanie to nie odwołuje się do ekskluzywnego kontekstu antycznych obywateli zajmujących się filozofowaniem, którzy przeznaczeni są do sprawowania funkcji kierowniczych w polis, lecz wyjaśnia ową naturę jako powszechną cechę ludzkiego sposobu bycia, która szczególnie wyraźnie ujawnia się u dzieci i młodzież. W związku z tym pojęcie ludzkiej ukształcalności czy zdolności do doskonalenia się jako zasada nowoczesnego wychowania zyskuje na znaczeniu przez to, że dorośli - niezależnie od tego, czy chodzi o naturalnych czy profesjonalnych wychowawców - wypełniając obowiązki wychowawcze, nie wiedzą, kim w przyszłości będą ich podopieczni. $Z$ tego właśnie powodu propagowane przez Arystotelesa wychowanie przez przyzwyczajanie Rousseau przekształca w wychowanie negatywne, którego nie można utożsamiać z przyzwyczajaniem i dyscyplinowaniem, lecz trzeba rozumieć jako rozszerzanie w uczących się ich horyzontu doświadczenia osobistego i wiedzy zdobytej dzięki obcowaniu z innymi przez nauczanie.

Podobną transformację można zaobserwować w odniesieniu do drugiej ze sformułowanych przez Rousseau zasad wychowania nowożytnego. Wychowanie przez przedmioty łączy wychowanie $\mathrm{z}$ doświadczeniem świata materialnego. $\mathrm{Z}$ pomocą pedagogicznie zaaranżowanych sytuacji uczący się wchodzą w interakcje, ale nie ze swoimi wychowawcami i nauczycielami, lecz z przedmiotami nieożywionymi. Tym sposobem Rousseau nawiązał do poglądów Platona, według którego kształcenie następuje dzięki zmianom kierunku patrzenia, dokonywanym przez samego uczącego się. Nie chodzi w nim o to, ,żeby człowiekowi wszczepiać wzroku; on go ma, tylko się w złą stronę obrócił i nie patrzy tam, gdzie trzeba" (Platon 1990: 366 [518 d 5-6]).

Rousseau w Emilu odwołuje się co najmniej kilkakrotnie do platońskiej koncepcji zmiany kierunku patrzenia. W szczególności chodziło mu o rozwijanie zmysłów małego 
dziecka, korygowanie jego wyobrażeń przestrzennych i czasowych, intepretowanie doświadczenia moralnego i w końcu koncypowanie takiego toku nauczania Emila, który będzie uwzględniał zróżnicowane formy wiedzy. W tej ostatniej sprawie paleta możliwości sięga od zdroworozsądkowego poznania życiowego do poznania naukowo-filozoficznego, które w jednakowym stopniu może być odniesione do stanów rzeczy fizykalnych, moralnych, jak i religijnych. To, co Platon napisał o oku i twarzy, że mianowicie temu pierwszemu nie da się włożyć wzroku, jeżeli jest ono pozbawione światła (tamże: 365 [518 c 2-3]), Rousseau rozszerzył na rozwój wszystkich zmysłów: dotyku, słuchu, powonienia i smaku, nie wyłączając z tego zmysłu wspólnego. Według omawianego autora zmysły rozwijają się nie według opisanej przez Arystotelesa zasady regresji od doświadczenia do jego przyczyn celowych, lecz przez negatywne doświadczenia i irytacje, których doznaje uczący się w trakcie interpretowania swoich doznań, po to, żeby je w konstruktywny i zarazem refleksyjny sposób przepracowywać.

Podobnej korekty arystotelesowskiej koncepcji wychowania przez przyzwyczajanie podjął się Rousseau w swoich rozważaniach dotyczących trzeciej zasady nowoczesnego wychowania - przez innych ludzi. Zastosował w niej wspomnianą powyżej platońską koncepcję kształcenia przez zmianę kierunku patrzenia jednak nie w odniesieniu do edukacji filozofów, lecz jako ogólną normę praxis pedagogicznej, która powinna mieć zastosowanie w wychowaniu wszystkich ludzi. Jak wiadomo, Arystoteles rozumiał siebie samego jako teoretyka wychowania polegającego na rządzeniu, które w pozytywny sposób normuje powołanie dorastających, i w związku z tym przewidywał rozszerzanie doświadczenia i wiedzy pochodzącej z kontaktów z innymi ludźmi za pomocą nauczania wyłącznie tych, których uważał za nadających się do prowadzenia życia teoretycznego. W przeciwieństwie do tego Rousseau zaprezentował ogólną koncepcję wychowania, w której całkowicie rezygnuje się z czynności rządzenia w sensie arystotelesowskim i zastępuje je wychowaniem negatywnym.

Swoją koncepcję wychowania negatywnego Rousseau opisuje, opatrując ją ważnymi od strony teoretycznej, ale jednocześnie problematycznymi i nierzadko również mylącymi wskazówkami. Do tych pierwszych należą niewątpliwie rozważania odnoszące się do wychowania małego dziecka:

Jedyną rzeczą, do której przyzwyczaić należy dziecko, jest brak wszelkich przyzwyczajeń; nie powinno się go nosić na jednej ręce częściej niż na drugiej, nie powinno się go przyzwyczajać do podawania jednej ręki raczej niż drugiej lub posługiwania się jedną raczej niż drugą; do domagania się pokarmu, snu, ruchów w tych samych godzinach ani do tego, aby nie mogło pozostawać samo czy to we dnie, czy w nocy. Z zarania już przygotowujcie je do korzystania ze swobody i do używania sił, pozostawiając ciału wrodzone jego zwyczaje, czyniąc dziecko zdolnym do tego, by zawsze panowało nad sobą i spełniało we wszystkim swoją wolę, skoro już wolę tę mieć będzie (Rousseau 1955a: 47-48).

Mylące natomiast są wskazania, w których mowa jest o tym, że wychowanie negatywne oznacza przeciwieństwo tego, co potocznie uważa się za właściwe. Przykładowo autor 
Emila zachęca do tego, żeby „nic nie czynić i nic nie kazać czynić” (tamże: 90), a także uważać „wszelkie opóźnienie za korzystne” (tamże: 91). Jednocześnie jednak wychowawca Jan Jakub podejmuje rozliczne zabiegi, mające na celu umożliwienie jego podopiecznemu uczenie się z własnych negatywnych doświadczeń. Przykładowo razem z Emilem wysiewa w ogródku nasiona na uprawionej już grządce w tym tylko celu, żeby uczący się zrozumiał, czym jest własność (tamże: 98-99); gubi się w lesie po to, żeby za pomocą pozycji słońca nauczyć Emila wyznaczenia kierunku w terenie (tamże: 219 i nast.); eksperymentuje z kijem zanurzonym w wodzie, który wydaje się złamany, żeby ponownie odkryć prawo załamania światła odkryte w 1704 roku przez Newtona (tamże: 257 i nast.); z negatywnych doświadczeń wikarego sabaudzkiego uczy rozróżniać między wypowiedziami przyrodniczo-naukowymi i religijnymi oraz między religią, religią cywilną i religią ojców (Rousseau 1955b: 87 i nast.); w końcu po zapoznaniu Emila z Zofią udaje się z nim w dziesięcioletnią podróż po Europie, żeby przekonać się, że nie ma ani jednego kraju rządzącego się zasadami Umowy społecznej (tamże: 383 i nast.). Do negatywnych doświadczeń przedstawionych przez Rousseau w pięciu księgach Emila dołącza się jeszcze jedno, które autor opisał we fragmencie zatytułowanym Emil i Zofia, czyli samotni. Emil konfrontuje się w nim z niewiernością swojej małżonki, porzuca ją i postanawia pozostać do końca życia samotny - bez Zofii i bez ojczyzny (Rousseau 1979).

Na podstawie powyższego akapitu widać, że Rousseau nie uzależnia wartości pedagogicznej negatywnych doświadczeń gromadzonych w trakcie procesu wychowania i kształcenia od końcowego happy endu. Notabene takiego happy endu w Emilu w ogóle być nie może, gdyż przez to jego autor zaprzeczyłby przeprowadzonej przez siebie krytyce społeczeństwa swoich czasów. Literacką fikcją jest zarówno powieść edukacyjna, jak i przywołany powyżej fragment stanowiący jej kontynuację. To, że Emil przeżył zdradę swojej małżonki, przebaczył jej i usunął się w samotność, jest tak samo wirtualne jak wszystko inne, co przedstawił Rousseau, wyjaśniając zaproponowaną przez siebie koncepcję nowoczesnego wychowania negatywnego, w którym centralną rolę odgrywa ukształcalność.

Niewirtualna jest natomiast teoria młodości, którą zaprezentował Rousseau w czwartej księdze Emila. Opisał w niej wiek dorastania jako moratorium, czyli czas oczekiwania i bycia „zawieszonym” między dzieciństwem a dorosłością. W okresie tym dorastający przekonują się, że naprawdę nie znają swojego powołania, lecz muszą je dopiero odkryć i rozwinąć w sobie. Według Rousseau w młodości wychowanie pozytywne jest niemożliwe. Młodzi ludzie zamiast koncypować swoją przyszłą determinację przez wejście w dorosłe życie, powinni raczej rozciągać możliwie jak najdłużej okres młodości. W ten sposób zyskują czas i przestrzeń dla kształcenia emocjonalnego i kognitywnego, które pomogą im w wyborze własnej drogi życia.

\section{Zakończenie}

W przeprowadzonych analizach autorzy wykazali, że pojęcie ukształcalności jest wielorako obecne w pismach J.J. Rousseau i stąd nie należy go utożsamiać wyłącznie z koncepcją 
Johanna F. Herbarta. Ukształcalność jako fenomen towarzyszy właściwie od zarania dziejów myśleniu, a jeszcze bardziej działaniu pedagogicznemu. Jednak jako pojęcie ukształcalność została odkryta i zwerbalizowana dopiero przez Rousseau na progu współczesności, stając się osnową jego dzieł poświęconych zarówno wychowaniu, jak i kwestiom filozoficznym. Z lektury jednych i drugich powstaje obraz człowieka, który zmuszony jest do poszukiwania własnego określenia czy powołania. Nakaz ten w szczególny sposób odnosi się do okresu dzieciństwa i młodości, choć nie utożsamia się z nimi. Człowiek będąc istotą z natury swej niezdeterminowaną i otwartą na stawanie się, dysponuje potencjałem, który można wykorzystać lub zmarnować. W nowoczesnej edukacji chodzi o to, żeby nie tylko nie zaprzepaścić owego potencjału, lecz przede wszystkim, żeby go wspierać i pomnażać. Patrząc od tej strony na zaprezentowane rozważania, wypada żywić nadzieję, że przyczynią się do uświadomienia zadań spoczywających na edukacji w zakresie wspierania indywidualnego rozwoju wychowanka. Jak się okazuje, Rousseau już 250 lat temu starał się zwerbalizować te zadania w projekcie edukacyjnym przedstawionym w Emilu. Jego aktualność nie wynika bynajmniej z ponadczasowości zaproponowanych w nim rozwiązań, lecz z tego, że kierunek wyznaczony myśleniu pedagogicznemu nie uległ właściwie żadnej zmianie.

\section{Literatura}

Arystoteles (2001), Polityka. W: Arystoteles, Dzieła wszystkie, t. 6. Warszawa, Wydawnictwo Naukowe PWN.

Benner D., Oettingen von A., Peng Zh., Stępkowski D. (2015), Bildung - Moral - Demokratie. Theorien und Konzepte moralischer Erziehung und Bildung und ihre Beziehungen zu Ethik und Politik. Paderborn, Ferdinand Schöningh Verlag.

Benner D. (2015), Pedagogika ogólna. Wprowadzenie do myślenia i działania pedagogicznego w ujęciu historyczno-problemowym i systematycznym. Warszawa, Wydawnictwo Uniwersytetu Kardynała Stefana Wyszyńskiego.

Benner D., Stępkowski, D. (2012), Jaskinia jako metafora opisujaca procesy kształcenia. Studium transformacji Platońskiej opowieści o jaskini $w$ dyskursach edukacyjnych. W: S. Sztobryn, M. Wasilewski, M. Rojek (red.), Metamorfozy filozofii wychowania od antyku do wspótczesności. Łódź, Wydawnictwo Uniwersytetu Łódzkiego.

Freeman D. (1983), Margaret Mead and Samoa: The Making and Unmaking of an Anthropological Myth. Harvard, University Press.

Horkheimer M., Adorno Th. W. (2010), Dialektyka oświecenia. Warszawa, Wydawnictwo Krytyki Politycznej.

Pico della Mirandola G. (2010), Oratio de hominis dignitate. Mowa o godności człowieka. Warszawa, Wydawnictwo IFiS PAN.

Platon (1990), Państwo. Warszawa, Wydawnictwo AKME.

Reitmeyer U. (2013), Perfektibilität gegen Perfektion. Rousseaus Theorie der gesellschaftlichen Praxis. Münster, Verlag Lit.

Rousseau J.J. (1955a), Emil, czyli o wychowaniu, t. 1. Wrocław, Zakład im. Ossolińskich - Wydawnictwo Polskiej Akademii Nauk. 
Rousseau J.J. (1955b), Emil, czyli o wychowaniu, t. 2. Wrocław, Zakład im. Ossolińskich - Wydawnictwo Polskiej Akademii Nauk.

Rousseau J.J. (1979), Emile und Sophie oder Die Einsamen. München, Winkler Verlag.

Rousseau J.J. (1956a), Rozprawa o naukach i sztukach. W: J.J. Rousseau, Trzy rozprawy z filozofii społecznej. Warszawa, Państwowe Wydawnictwo Naukowe.

Rousseau J.J. (1956b), Rozprawa o pochodzeniu i podstawach nierówności między ludźmi. W: J.J. Rousseau, Trzy rozprawy z filozofii społecznej. Warszawa, Państwowe Wydawnictwo Naukowe.

Rousseau J.J. (2009), Umowa społeczna. Kęty, Wydawnictwo Marek Derewiecki.

Schäfer A. (2009), Dier Erfindung des Pädagogischen. Paderborn, Verlag Ferdinand Schöningh.

Stępkowski D. (2010), Ukształcalność jako zasada działania edukacyjnego. W sprawie zapomnianej kategorii Herbarta i jej współczesnej reinterpretacji. W: M. Kowalski, A. Pawlak, A. Jamuła-Jurczak (red.), Przestrzeń edukacyjna - dylematy, doświadczenia i oczekiwania społeczne. Kraków, Oficyna Wydawnicza „Impuls”. 